\title{
Distraksiyon osteogenezinin histoloji ve biyolojisi
}

\section{The histology and biology of distraction osteogenesis}

\author{
Vecihi Kırdemir \\ Süleyman Demirel Üniversitesi Tıp Fakültesi Ortopedi ve Travmatoloji Anabilim Dalı, Isparta
}

\begin{abstract}
1950'li yıllarda eksternal fiksatör dizayn etmeye başlayan Prof. Dr. Gavriil Abramovich llizarov, bu alet ile ilk kırık tedavisine 1945 yılında başlamıştır. Ilizarov, kırık tedavisi için ilizarov eksternal fiksatörü ile tespit uygulanan bir hastasının, rodlardaki vidaları sıkıştıracağına yanlışlıkla vidalarını gevşetmesi sonucunda kırık hattında yeni kırık kaynaması oluşmasını gözlemesi ile uzatmaya bağlı kırık hattında oluşan değişiklikleri izlemiştir. 1969 yılında "The course of compact bone reperative regeneration in distraction osteosynthesis under different conditions of bone fragments fixation (experimental study)" adlı makalesinde 10 yıllık deneysel çalışmalarını yayımlamıştır. Yayımlanan bu çalışmasında, 65 köpekte incelediği distraksiyon osteogenezisini ve sonuçlarını belirtmiştir. Deneyleri sonucunda; en uygun koşullardaki stabil bir fiksasyon sayesinde düşük enerji ile yapılan osteotomi sonrası, 5-7 gün bekleme süresine ilaveten 6-8. günden sonra osteotomi hattında, günde 3-4 defada tamamlanan 1 mm'lik uzatmanın gerçekleşeceğini tarif etmiştir. Ilizarov'un bu tekniği daha sonra insanda uygulanmış ve "Distraksiyon Osteogenezi" adıyla yaygın olarak kullanılmaya başlanmıştır.
\end{abstract}

Anahtar sözcükler: distraksiyon osteogenezi; histoloji; biyoloji
In the 1950's, he designed the external fixator. Dr. Gavriil Abramovich Ilizarov started the first fracture treatment in 1945 with this device. Ilizarov observed changes in the fracture line due to lengthening by observing the formation of a new fracture union in the fracture line as a result of accidentally loosening the screws on the rods of a patient who was fastened with the Ilizarov external fixator for fracture treatment. In 1969, he published his 10year experimental work in his essay compact The course of compact bone reparative regeneration in distraction osteosynthesis under different conditions of bone fragments fixation experimental (experimental study). In this published study, he reported distraction osteogenesis and results in 65 dogs. As a result of the experiments; Stable fixation under optimal conditions allows low-energy osteotomy to allow 5-7 days in addition to waiting for 6-8. described an extension of 1 millimeter $(\mathrm{mm})$ in the osteotomy line after 3-4 days. This technique of Ilizarov was later applied in humans and became widely used as Distraction Osteogenesis.

Key words: distraction osteogenesis; histology; biology
1 950'li yıllarda eksternal fiksatör dizayn etmeye başlayan Prof. Dr. Gavriil Abramovich Ilizarov, bu alet ile ilk kırık tedavisine 1945 yılında başlamıştır. Ilizarov, kırık tedavisi için ilizarov ekstrenal fiksatörü ile tespit uygulanan bir hastasının, rodlardaki vidaları sıkıştıracağına yanlışıkla vidalarını gevşetmesi sonucunda kırık hattında yeni kırık kaynaması oluşmasını gözlemesi ile uzatmaya bağlı kırık hattında oluşan değişiklikleri izlemiştir. 1969 yılında "The course of compact bone reperative regeneration in distraction osteosynthesis under different conditions of bone fragments fixation (experimental study)" adlı makalesinde 10 yıllık deneysel çalışmalarını yayımlamıştır. Yayımlanan bu çalışmasında 65 köpekte incelediği distraksiyon osteogenezisini ve sonuçlarını belirtmiştir. ${ }^{[1-4]}$
Deneyleri sonucunda; en uygun koşullardaki stabil bir fiksasyon sayesinde düşük enerji ile yapılan osteotomi sonrası, 5-7 gün bekleme süresine ilaveten 6-8. günden sonra osteotomi hattında, günde 3-4 defada tamamlanan 1 milimetre $(\mathrm{mm})$ 'lik uzatmanın gerçekleşeceğini tarif etmiştir. Ilızarov'unbu tekniği daha sonra insanda uygulanmıştır.

Bu tekniğin başarılı olmasının altında yatan nedeni anlamak için kemik fizyolojisini hatırlamakta fayda vardır. Bilindiği gibi osteotomi sonrası oluşan her iki kemik yüzeyi arasında distraksiyona (uzaklaşmaya) bağlı yeni trabeküler kemik dokusu gelişmektedir. Radyolojik olarak görülmeyen bu doku, bir fibröz dokudur. Yeni kemik dokusu bu iki osteotomi yüzeyleri arasındaki kollajen köprüsü üzerinde gelişmektedir.

- Illetişim adresi: Prof. Dr. Vecihi Kırdemir, Süleyman Demirel Üniversitesi Tıp Fakültesi, Ortopedi ve Travmatoloji Anabilim Dalı, Isparta Tel: 0542 - 8117575 e-posta: vkirdemir@gmail.com

- Geliș tarihi: 6 Aralık2019 Kabul tarihi: 20 Ocak2020 
Kollajen lifler ve kan damarları distrakte edici güçlerin yönüne paralel olarak dizilir. Distraksiyonun sonunda, kemik hücreler mikrokolonlar halinde yoğunlaşır ve süratle ilk kemik şekline benzer bir hale gelirler. Bu döneme konsolidasyon dönemi denmektedir. ${ }^{[2]}$

Distraksiyona bağlı kas boyundaki \%10 oranında olan uzamalar kas tarafindan tolere edilebilir iken kas boyunun \%30'undan fazlasında olan uzamalarda ise kasta histopatolojik önemli değişiklikler gözlenmektedir. Ayrıca distraksiyona bağlı sinirde, arterlerde ve venlerde de geçici histopatolojik değişiklikler olmaktadır. Uzamadan iki ay sonra ise bu geçici değişiklikler kaybolmaktadır. Tavşanlarda yapılan tibia uzatmalarında, diz ekleminin kıkırdak yüzeyinde de kısa süre sonra histopatolojik değişiklikler gözlenmiştir. Bu gözlemlere göre büyüme kıkırdağının hipertrofik ve proliferatif zonun kalınlığının azaldığı bildirilmiştir. ${ }^{[2,3]}$

Gavriil Abromovich Ilizarov, 1990-1995'li yıllarda uzatma prensiplerini o yıllardaki histoloji ve fizyoloji bilimi kuralları çerçevesinde bu şekilde izah etmiştir. ${ }^{[2]}$ Oysa günümüzde histoloji ve fizyoloji bilimi aşağıdaki tarihsel örneklerde olduğu gibi çok farklı bir noktaya gelmiştir.

1990'lı yıllarda Nobel Tıp Ödülü E. Donnall Thomasan tarafindan hematopoetik kök hücre nakli ile alınmıştır. ${ }^{[5]}$

2001 Nobel ödülünü alan Tim Hunt ve Paul Nurse hücre döngüsünün anahtar düzenleyicilerini keşfetmişlerdir. ${ }^{[6]}$

2012 yılında ise Nobel Tıp Ödülü erişkinde farklılaşmasını tamamlamış cilt fibroblastlarının yeniden programlama ile kök hücrelere dönüştürebildiğini gösteren Ingiliz Sir John Garden ve Japon Shinya Yamanaka'ya ortaklaşa verilmiştir. Bu ikili ayrı ayrı farklılaşmış hücrelerden bile yeniden kök hücre oluşturabileceğini göstermişlerdir. ${ }^{[7]}$

Ilizarov bir 'yanlışık' sonucu kırık iyileşme prensiplerini nasıl değiştirmiş ise, günümüzde de Thomasan ve Hunt-Nurse ikilisi, Garden ve Yamanaka'ya ait "Kök Hücre" $(\mathrm{KH})$ çalışmaları ile, $\mathrm{KH}$ tanımlanması ve kavranmasına bağlı olarak kırık iyileşmesi yeni prensipler ışığında değerlendirilmelidir. Kemik oluşumu, kırık iyileşmesi yanında uzatma prensipleri de yeni bilgiler ışığında değerlendirilmelidir. ${ }^{[8-10]}$

Bugünkü bilgilerimize göre erişkin bir insanda kırılan bir kemiğin iyileşmesi için o bölgenin çoğalabilme kapasitesi olan erişkin=adult tipi kök hücreler $(\mathrm{AKH})$ ile doldurulmasına, doldurulan bu dokunun yeniden şekillenmesine ihtiyacımız vardır.

Erişkinde, herhangi bir dokuda hasar oluştuğu zaman yeni doku oluşturulması için organizmanın kullandığı en kolay yöntem; embriyoda o doku oluşurken yapılanların taklit edilmesidir. Bu yüzden bu yazıda; embriyodaki kemik oluşumunun nasıl gerçekleştiğini tekrar hatırlatmak isterim. Çünkü distraksiyon histiogenezis'ini gözlemlemek isteyen bir hekim ilk olarak istediği bölgede kırık oluşturur. Sonra vücut içine ya da dışına yerleştirdiği aletler ile ister kırık uçlarını sabitleyip ister kırık uçlarını hareket ettirerek kırık iyileşmesini ulaşmak istediği sonuca göre yönlendirmeye çalışır.

Yazıda kırık oluşturma, kırıktaki dokuların iyileşmesi, kemik yük taşıma fonksiyonlarının yeniden kazanılmaSı, yerleştirilen aletlerin iyileşmeyi nasıl kontrol ettiği açıklanmaya çalışılacaktır. Çünkü distraksiyon osteogenezisi distraksiyon devam ettiği sürece, yeni kırık oluşumu ve kırık iyileşmesinin tekrarlamasından ibaret bir biyolojik ve histolojik süreçtir.

\section{KIRIK NASIL IYILEŞIR?}

Kırık kendiliğinden iyileşebildiği gibi yalancı eklem (pseudoartroz) veya deformite oluşturacak (malunion) şekilde de iyileşebilir.

Kırıklar, tedavilerinin ortopedi ve travmatoloji uzmanı tarafından yapıldığı durumlarda ya da kendiliğinden iyileştiğinde ilk meydana gelen olay; kırık boşluğunun tamirini sağlayacak doku veya dokular ile doldurulmasıdır.

Boşluğu ilk dolduran orijinal kemik dokusu değildir. Dolayısıyla iyileşme tamamlana kadar bu boşluk çeşitli dokular ile doldurulacaktır. Boşluk oluşmuş kırıklarda boşluğun hemen yanında hasarlı kemik dokusu vardır. Hasarlı dokuların ve bu tamir dokularının kaldırılması için fagositik hücrelere ve enzimlere ihtiyaç vardır. Bu fagositik hücreler ve enzimler immün sistem tarafından sağlanacaktır.

Çökme ve torus gibi kırık tiplerinde boşluk yoktur, sadece hasarlı kemik doku ve bu doku içindeki bütünlüğü bozulmamış ama katlantıları nedeni ile içindeki dolaşımı bozulmuş damar sistemi vardır. Stres tipi kırıklarda ise Haversian, Volkman sistemi ve dolaşım da bozulmamıştır. Lezyon sadece kemik dokuyu içerir. Kemik doku matriksi osteoklastlarca parçalanıp yeni osteoblastlar ve onların oluşturduğu yeni matriks ile iyileşme tamamlanır inflamasyon oluşmaz (rejenerasyon) (Şekil 1).

Torus ve çökme tipi kırıklarda ise Haversian ve Volkman sistemi bütünlüğü bozulmamış fakat damarlar katlanmış bu neden ile dolaşım bozulmuştur. Bu tip kırıklarda dolaşım bozukluğu inflamasyona neden olacaktır. İnflamatuvar moleküller (sitokinler, büyüme faktörleri vb.) erişkinlerdeki kök hücrelerin (AKH) çoğalma ve farklılaşma (pluripotency) özelliğini uyararak, lokal cevap ile primer iyileşme sağlanacaktır. 


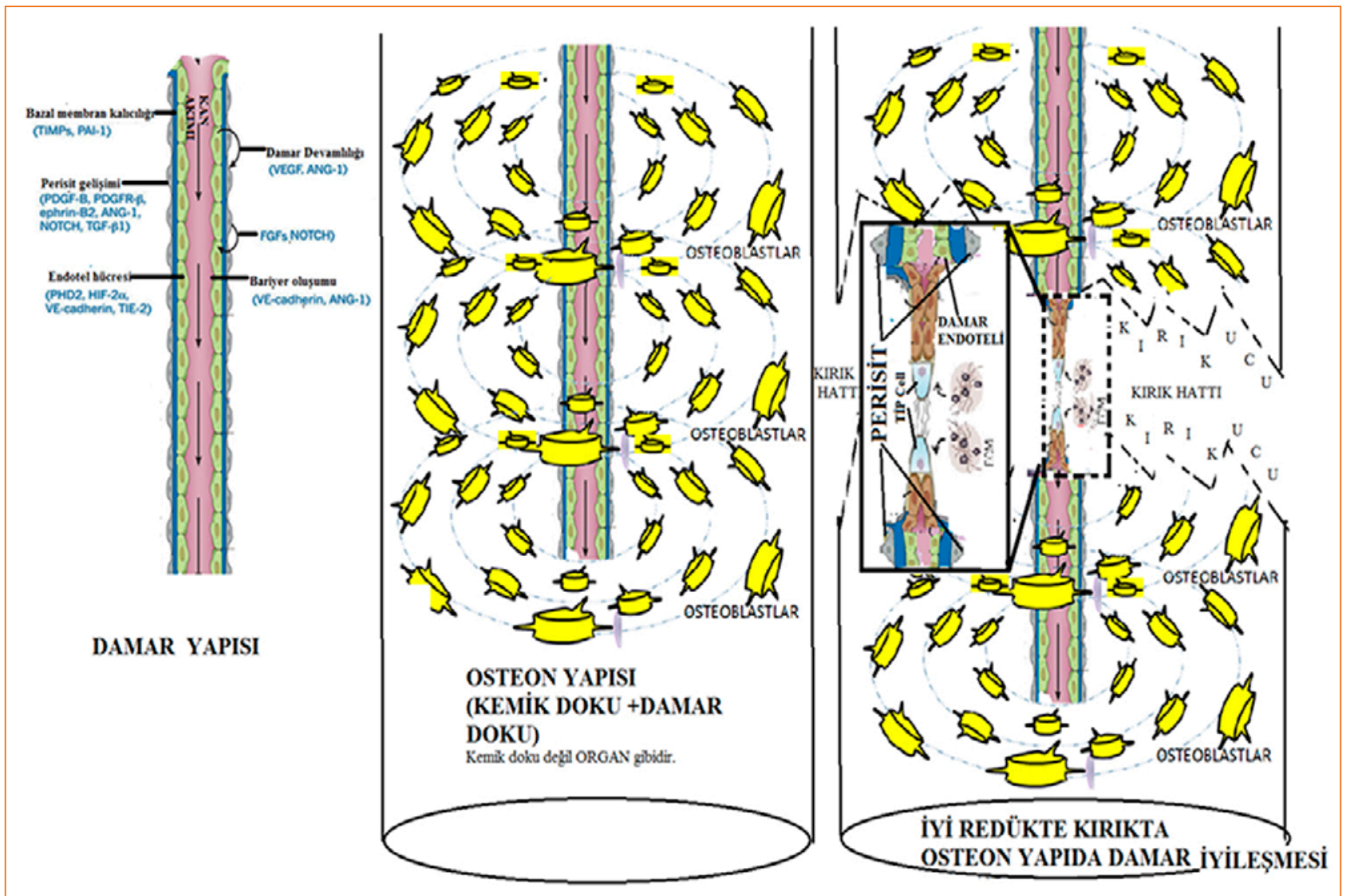

Şekil 1. Kemik doku ve damar bütünlüğünün sağlanması. Damar bütünlüğü bozulduğunda damar bütünlüğünün yeniden sağlanması.

\section{İnflamasyon ve Kök Hücre Kavramları Ne Ifade Ediyor?}

Yazının başında da bahsedildiği üzere 2000'li yıllardan itibaren kök hücre ve inflamasyon terimleri, ilk kullanıldıkları dönemlerindeki anlamları ifade etmemektedirler. İnflamasyon ilk kez Hipokrat tarafından ifade edilmiş olsa da bugün hasarlı dokunun, kendine zarar veren etmeni tanıması ve yok etmesi için damar içi elemanlar ile başlayan bir süreçtir. Bu süreç sonunda zarar veren etmen ortadan kaldırılabilir veya kaldırılamaz. Kaldırılmış olsa bile bu süreç dokuya, organa veya organizmaya zarar verebilir. Süreç organizmanın yararına sonlanır ise iyileşme tamamlanır. Sürecin iyi takip edilmesi ve firsat var ise müdahaleler yapılması günümüz tıbbının görevi olmuştur. Süreç yönetimi bilgi düzeyi ve teknoloji ile yakın ilişkilidir.

Kök hücre terimi ise ilk kez 1868 yılında Alman bilim adamı Ernst Haeckel tarafından kullanılmış 1909 yıIında Rus bilim adamı Alexander Maximov tarafından hematopoetik sistem ana hücresi için kullanılmıştır. Bugün o kadar bilimsel çalışma yapılmasına rağmen geldiğimiz nokta bu iki bilim adamının söylemi üzerine oturmuş gibidir.

1- Ernst Haeckel'ın tanımı ile Embriyonik Kök Hücre (EKH) [embriyolojideki ana hücrenin (zigot) çoğalması farklılaşması sonucu doku-organ-sistemlerin-organizmanın gelişmesi]

2- Alexander Maximov'un tanımı ile Erişkin=Adult Kök Hücre $(A K H)$ [ erişkindeki tamir ve rejenerasyon işlemleri] parelel hale gelmiştir.

Her iki bilim adamı kendi zamanlarında mitoz sonrası oluşan iki yavru hücrenin de kendi kök hücresinin karakterini ifade ettiklerini düşünüyordu. Günümüzde ise bu hipotezin aksine farklı olan yavru hücrelerin farklılaşma özelliği kazanmaları ve erişkinde AKH'lerin çoğalma sonrası self-renewal = kendini yenileme sistemini kullanarak KH sayısını sabit tutmaya çalışması ve maligniteye fırsat tanımama eylemi içinde olmaları keşfedilmiştir (Şekil 2). 


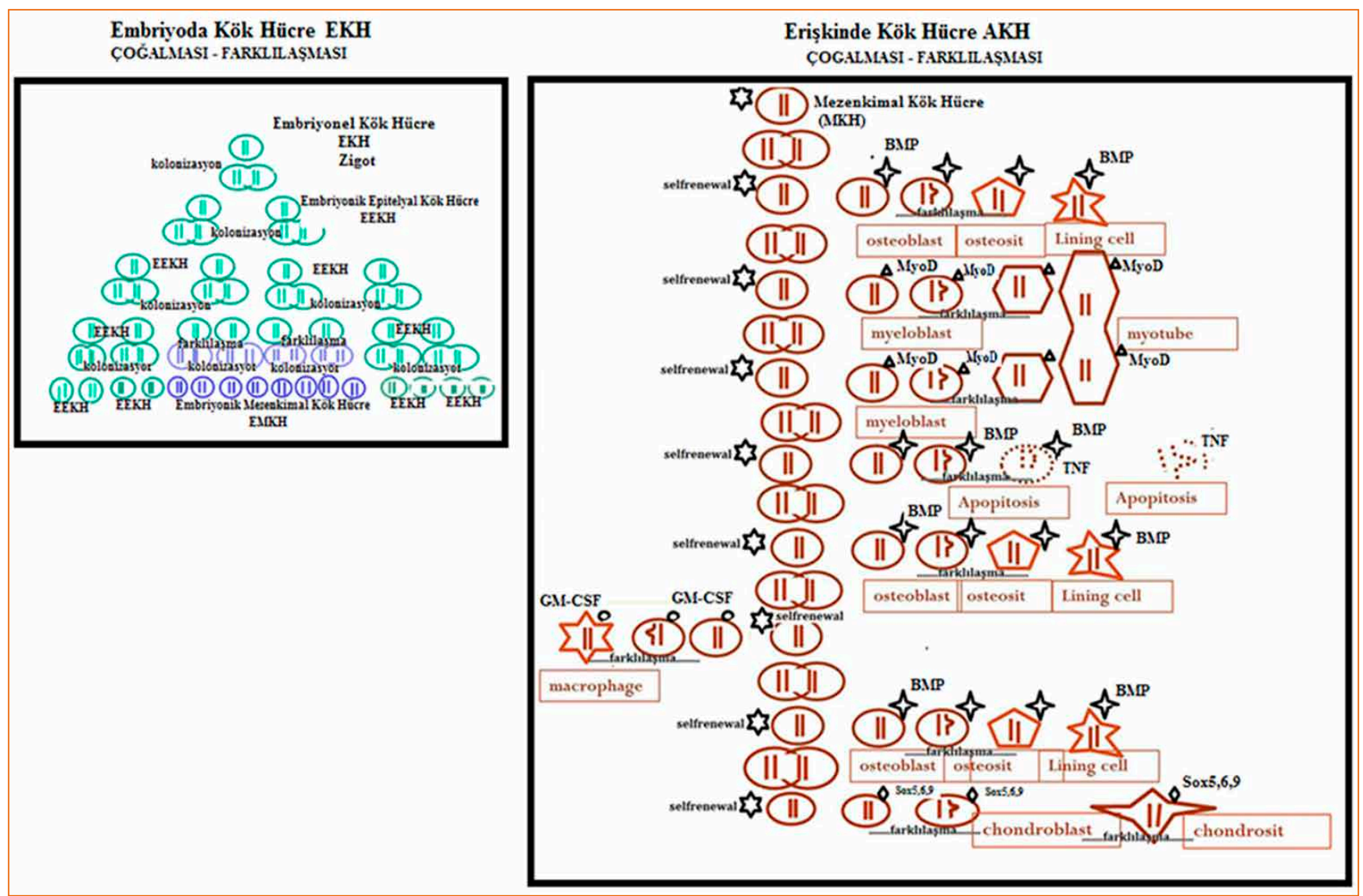

Şekil 2. Embriyoda ve erişkinde kök hücre çoğalması ve gelişmesi arasındaki farklar.

Günümüzdeki diğer önemli bir fark ise embriyoda KH'ler her yerde bulunur iken erişkinde AKH'ler Niş adı verilen özel bölgelerde bulunmalarıdır. Erişkindeki nişler kemik iliği (Ki), damar çevresi perisitler, kas dokudaki satellit hücreler, dolaşan kan, kıl kökü, ince barsak villüsleri epiteli, yağ doku vb. yerlerdir. Nişlerde istirahat $\left(G_{0}\right)$ fazındaki AKH'ler, ihtiyaç halinde sitokin ve büyüme faktörlerinin etkisiyle çoğalmaya-farklılaşmaya başlarlar. Dolaşan kan içinde nişlerden çıkıp sisteme katılan KH'ler ihtiyaç halinde lazım olan dokularda çoğalıp farklılaşabilirler. Eğer dolaşımda kendilerine ihtiyaç duyulmaz ise dönüp kendi nişlerine geri dönerler. Buna "homing" = yuvaya dönüş denir.

Bununla birlikte hasar durumunda organ ve dokuların bütünlüğünü, beslenmesinin bozulmasını daha hızlı düzeltmek için daha çok görev düşer. Damar bütünlüğünün bozulduğu durumlarda perisit tip hücrelere farklılaşıp çoğalarak angiogenezisi oluşturmaya çalışırlar. Dolaşan kan içindeki MKH ise çoğalıp fibroblastlara farklılaşır. Dolaşan kanda MKH sayısının az olması yakın çevrede başka niş olmaması halinde perisitler Epitel Mezenkim Transition = geçiş $(\mathrm{EMT}=\mathrm{EMG})$ yolunu kullanarak MKH dönüşür. Düzensiz damar tomurcukları ve fibroblastlardan oluşan bu yapıya granülasyon dokusu denir.

Bu yüzden Erişkin Kök Hücreler (AKH) doku ve organların fizyolojik yenilenmesi ve tamirinde görev alırlar. Yenilenmede (rejenerasyon) AKH sadece orijinal doku hücrelerine farklılaşırken, tamir (reperasyon) olayında $\mathrm{AKH}$ orijinal dokudan önce granülasyon dokusunu oluştururlar. Tamir dokusu dışında AKH hasarlı dokuyu ya da hasar verici etmenleri yok edecek immün sistem hücrelerine (makrofaj) de farklılaşır.

Embriyoda EKH çoğalması ve farklılaşması kalıtım ile kontrol edilir. Organogenezis ve fetus gelişiminde apopitozis önemli yer işgal eder. İmmün sistem geliştikten sonra embriyoda da makrofajlar işlem yapmaya başlarlar. Fakat erişkinlerde hasarlı dokuların kaldırıması için makrofajlara önemli bir görev düşmektedir. Erişkinde AKH'lerin çoğalması ve farklılaşması için genetik bilgiler dışında büyüme= "growth" faktörleri ve sitokinlere de ihtiyaç duyulmaktadır. Problem olmadıkça her şey kalıtım ile işlerken hasar durumunda inflamasyon dediğimiz süreç başlar. 
İnflamasyon süresinin uzun sürmesi durumunda AKH'ler daha fazla sürede ve daha fazla çeşitte sitokin etkisine maruz kalırlar. Hasarlı dokunun ilk (orijinal) hali ile onarımın bittiği hali arasında geçen sürede farklı bağ ve destek doku (fibröz-kıkırdak-kemik doku) şekilleri gözlenir.

Hasar gören doku mezenkimal kökenli ise tamir sürecinde ilk olarak fibroblastlar, fibroblastların oluşturduğu matriks ve bu dokuyu beslemeye yönelik angiogenezise bağlı bir tamir dokusu (granülasyon dokusu) gözlenir. Hasar görmüş doku epitel kökenli ise ve de bazal membran etkilenmiş ise doku orjinal haline geri dönemez. Bazal membranın altındaki mezenkimal dokuda işleme katılır. Angiogenez ve fibrozizis oluşur. Bu da membranın üzerindeki epitel dokuda düzensizliğe neden olur.

İnflamasyonu tanımladı̆̆ımızda aslında; 1. Hasar veren etmeni tanıma, 2 . Onu ortadan kaldırma ve 3 . Tamir işlemlerinin tamamını kast ederiz.

\section{Hasar Yapıcı Etmenlerin Tanınması ve İmmün Sistem ile Cevap Verilmesi}

İyileşme için öncelikle hasar yapıcı etmenin tanınması ve ortadan kaldırılması gerekir. Tanıma ve kaldırma işlemi immün sistem tarafından yapılacaktır. Çoğu kez hasar yapıcı etmen (infeksiyon, yabancı cisimler gibi= "Pathogen Associated Molecular Patterns" [PAMPs]) ve hasar birliktedir. Bu durumlarda immün sistem hem etmeni tanımaya hem de ona cevap vermeye çalışır.

Dokuda mevcut (Osteoklast, Kupfer, Langhans vb.) ya da dolaşan kandaki makrofajlar ile dokuya yabancı mikroorganizmalar ve moleküller fagosite edilmeye çaIışılır. Bu yabancı madde ve organizmalar fagosite edilemiyor ise kan plazması içinde bulunan moleküller ile kaplanması (koagulum, kompleman, antikor gibi) ve vücuttan tecrit edilmesi sağlanır. Hasarlı doku mezenkim kökenli ise tecrit işlemine doku matriksi de yardımcı olur. Fibröz matriks kılıf ya da osteoid matriks kılıf "totan lade"(ölü tabut) ile çevrilir (apse, Brodie apsesi, osteoid osteoma vb.).

Kırı tedavisinde kullanılan ortopedik implantlar ve greftlerde birer yabancı cisimdir. İmmün sistem bunları da yabancı cisim olarak algılar ve bu aletlere karşı lokal immün cevap oluşturur. Bunun için implant ya da greftler fagosite edilemeyecek kadar büyük oldukları için tecrit yöntemi kullanılır. Etrafları koagülümden oluşmuş matriks ve buna tutunan bir iki kat fibroblastlardan oluşturulmuş fibröz bir doku ile kaplanır.

Hasar yapıcı etmen yabancı mikroorganizmalarya da moleküllerden (PAMPs) değil aksine travma, donma, yanık, maligniteler gibi etmenlerden kaynaklanıyor ise hasarlı dokuda immün yanıt işlemi için gerekli antijenik moleküller ortamda bulunmaz. Yabancıyı tanıma derdi olmadığı için dokulardaki ya da dolaşan kandaki immün sistem hücrelerinden kaynaklanan kimyasal moleküllere ihtiyaç duyulmaz. Bu durumda doğal immunite adı verilen ve türe özgü moleküllere (kinin-bradikinin sistemi, koagülasyon sistemi, kompleman sistemi, akut faz reaktanları v. b.) de ihtiyaç duyulmaz. Hasarın kendisi ya da tamir etmek için yapılan işlemler (redüksiyon, insizyon, yaklaşım, ekartasyon, otogreft) sonucu ortama çıkan doku molekülleri antijenik özellik kazanır (DAMP = Danger-Associated Moleculer Patterns). Bu moleküller de immün cevap işlemini başlatır. Bu cevap doğal immün cevap değil, kazanılmış immün cevap mekanizması üzerinden olur. Bu yüzden bu cevap daha geç sürede gerçekleşir.

PAMP ya da DAMP'lar sayesinde başlayan immün cevap ile doku ya da dolaşan kandaki immün hücreler ve immün moleküller hasarlı dokuya göç etmeye başlarlar.

Kök hücreler akut inflamasyonda kimyasal yöntemler ile (antijen tanıma yeteneği ve antikor salgılama yeteneği daha fazla olan) çalışan immün hücrelere (B-Lenfosit) farklılaşır (hümoral kazanılmış immünite).

Kronik inflamasyonlarda ise kök hücreler fagositik yöntemleri kullanan immün hücrelere (T Lenfosit) farklılaşır (hücresel kazanılmış immünite). Bu yüzden kronik inflamasyonlarda hücresel immün sistemin baskın olduğu (fagositoz) bir doku yıkımı gözlenir.

Doku yıkımı fazla olduğundan kök hücrelerin çoğalıp orijinal dokuya da farklılaşması gerekir. Kök hücreler hem immün hücrelere hem de hasarlı doku hücrelerine dönüşmeye çalışırlar. Bu durumda KH'nin, ne tip hücreye dönüşeceğine karar verecek mekanizmalar ortaya çıkar. Karar verme mekanizmaları kimyasal moleküller ya da mekanik etkilere bağı çalışırlar. Aslına baktığımızda mekanik etkilerde matriks içinde ve hücre membranında bulunan proteoglikan moleküllerin gerilme ve gevşemeleri üzerinden etkili olur. Ama bu işlem hızlıca yapılamaz.

\section{FiZYOLOJIK YENILENME ve INFLAMATUVAR CEVAP ILE YENILENME}

Yazımızın başında kök hücrelerin doku ve organların fizyolojik yenilenmesi ve tamirinde görev alacaklarını belirtmiştik. Fizyolojik yenilenmelerde $\mathrm{KH}$ sitokinlerin, büyüme faktörlerinin ve hormonların fizyolojik salınım düzenine göre hareket ederken tamir olayında ise bu işlemler lokal immün hücreler ve bunların salgıladıkları sitokinlerin salınımlarına göre başlatılır ve sürdürülür.

Hasarlı bölgedeki lokal sitokinlerin KH'den yeni doku için "progenitor" hücre oluşturmadan önceki ilk işleri; hasarlı dokunun lokal damarların geçirgenliğini 
değiştirerek a) sıvı artışı b) ısı artışı c) hacim artışı d) renk değişikliği e) fonksiyon bozukluğu yaparak lokal inflamasyonu başlatmalarıdır. Amaç; hasarı sınırlamak, hasara sebep olan etmeni ortadan kaldırmak, hasarlanan dokuyu tamir etmektir (lokal inflamatuvar cevap).

Ortadan kaldırılmak istenen etmen enfeksiyonlardaki mikroorganizmalar, malign ya da istenmeyen hücreler, yabancı cisimler (ortopedik implant, greftler) ise hasarı sınırlamak ve yok etmek dokuyu tamir etmekten daha önemlidir.

Kırığın ilk saatlerinde vücudun canlılığını sürdürebilmesi ve hasarı kontrol etmek için bölgenin dolaşımı vazokonstrüksiyon ile kesilmeye (tecrit) çalışılır. Amaç kanamayı durdurmanın yanında daha sonra da dolaşımdan gelecek sitokinler ile dolaşıma katılacak lokal sitokinlerin sınırlı giriş-çıkışlarını sağlamaktır.

Lokal sitokinler yakın bölgedeki serbest sinir uçlarını ve damar geçirgenliğini değiştirip lokal etkiler başlatır. Bu bölgedeki nişlerde (nische) ve dolaşan kanda bulunup kırık hematomu içinde kalmış mezenkimal kök hücre $(\mathrm{MKH})$ 'lerin çoğalmasını ve farklılaşmasını başlatırlar (lokal inflamatuvar cevap).

Sitokinler bölgedeki nişlerdeki kök hücrelerin yanı sıra sistemik dolaşıma katılıp bölge dışındaki nişlerdeki kök hücreleri de uyarıp çoğalmalarını ve farklılaşmalarını, bölge dışındaki damar ya da endotel geçirgenliğinin değişmesini sağlayabilir. Uzak yerlerdeki alveol epiteli, duramater epiteli gibi hücrelerde değişikliklere neden olabilir. Uzak yerlerdeki bazal membranların geçirgenliği değişir. Alveol içi ve santral sinir sistemi içi ödem artabilir. Buralardaki kök hücreler immün hücrelere farklılaşmaya ve immün reaksiyonlara sebep olabilirler. Lokal olay sistemik bir hale gelebilir (sistemik inflamatuvar cevap).

İmmün sistem, aynı zamanda inflamatuvar yanıtları organizmanın dengesini bozmaması için denetlemeye çalışır. Hasarı oluşturan etmen varsa ortadan kaldırılmaya, yoksa sadece hasar onarılmaya çalışıı. Bu immün reaksiyonların kendisi de bazen lokal ve sistemik yeni hasarlara sebep olabilir. Kompanse edilemeyen inflamatuvar cevap sendromu oluşabilir. Bu olay, çoklu organ yetmezliğine (multipl organ failure -MOP) sonrasında da ölüme kadar gidebilir. Lokal bölgede ise kompanse edilemeyen inflamatuvar cevap kompartman sendromuna neden olabilir.

Kompanse edilemeyen immün cevapta birincil etmen immün sistemin aşırı çalışması olsa da, ikincil etmen MKH'lerden yeterli anti-inflamatuvar hücreler ve sitokinler oluşmamasıdır. Hasar büyük olsa bile immün sistem yeterince anti-inflamatuvar sitokin üretiyor ise inflamatuvar cevap sendromu kompanse edilir.
Hasarın büyüklüğü, hasar sonucu oluşan moleküllerin miktarı, tedavi yöntemleri, immün sistemin aşırı ya da yetersiz cevabını etkileyerek kompansasyonun şeklini belirler.

İnflamatuvar cevap kompanse edildiğinde zamana bağlı olarak tamir edilen doku çeşitli bağ doku tipleri ile doldurularak orijinal haline dönüştürülmeye çalışıır (Hematom-Fibroz-Kıkırdak-Kemik Doku).

\section{HEMATOM KÖPRÜ (KALLUS) DÖNEMi}

Kırık sonrası kırık hattı sıkıştırıcı (compression) kuvvetler etkisinde ise kırık hattında boşluk oluşmaz (Örneğin; kompresyon, torus kırığı) fakat gerici (distraction) tip kuvvetler etkisinde ise bir boşluk oluşur (yeşil ağaç kırığı = green stick, çok parçalı, kırık uçlarının yer değiştirdiği kırıklar).

Bu kırık boşluk bütünlüğü bozulan Haversian ya da Volkman sistemini oluşturan damar ağızlarından akan kan ile doldurulur. Kırık boşluğunu dolduran kan hacmini (hematomu) damar içi hidrostatik basınç ile kırık boşluğunun içindeki hidrostatik basınçlar arası fark belirler. Basınçlar eşitlenince kan akımı durur ve açık damar ağızları pıhtı ile tıkaçlanır. İlk bir hafta içinde kırık uçları arası ilk köprü (kallus), kanın sıvı matriksi (plazması) içindeki fibrinojenin fibrine dönüşmesi ile oluşan kolloid matriks (pıhtı) sayesinde sağlanır.

Kolloid matriks sertleşince, pıhtı içinde kalmış makrofajlarca ya da hemen yakındaki sağlam kalmış kemik doku içindeki osteoklastlarca kısmen parçalanır. Kırık hattına en yakın kök hücrelerden gelişecek fibroblastlara ve fibröz matrikse yer açılmaya çalışılır.

Hematom içindeki hücrelerden salgılanan sitokinlere, doğal immünite molekülleri ve kırık bölgesindeki hasarlı hücrelerden salınan sitokinler de ilave olur. Bu sitokinler kırık bölgesindeki serbest sinir uçlarını uyarır (elektriksel etki) ve ağrı oluşur. Sitokinler damar geçirgenliğini artırarak bölgenin kanlanmasını ve damar içi bazı moleküllerin hasarlı bölgeye ve de tersine hasarlı bölge kaynaklı moleküllerin de dolaşıma geçmesini (kimyasal etki) sağlarlar (Şekil 3).

\section{FiBROZ KÖPRÜ (KALLUS) DÖNEMI}

Illk üç gün içinde kırık yüzeyleri arasında fibrinojen matriks çatısı (scaffold) üzerine kurulmuş fibroblastları içeren bir bağ ve destek doku bileşimi (kompoziti) oluşur.

Bu süreçte; kırık hematomu içinde kalan eritrosit, lökosit ve trombositlerin apopitozunu ve nekrozunu, iskemik kemik ve yumuşak dokudaki hasar görmüş 


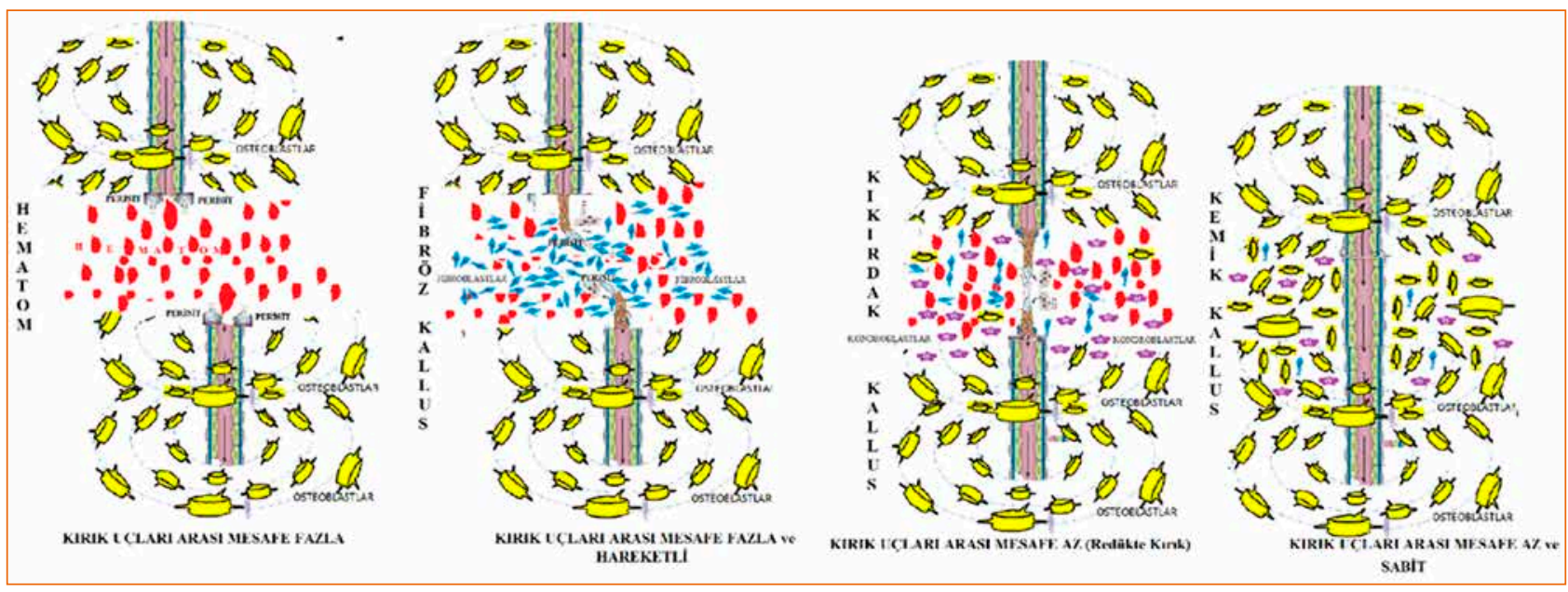

Şekil 3. Kırık uçlarında mesafe fazla olması ya da hareket olması durumunda granülasyon dokusu ve kırık iyileşmesindeki farklılıklar.

hücrelerin apopitozunu, osteoklastlar ve makrofajlarca yapılan yıkımı da gözleriz.

$\mathrm{Bu}$ dönemde $\mathrm{MKH}$ 'er çoğalmaya ve farklılaşmaya devam ederler. Şöyle bir örnekleme ile konuyu anlamayı kolaylaştırmak istersek: çoğalan her 10 kök hücreden yedi tanesi fibroblasta, birtanesi kondroblasta, bir tanesi osteoblasta, bir tanesi de fagosit hücrelere dönüştüğünü düşünelim. Benzer oranlarda devam eden çoğalma ve farklılaşmalar sonucu kırık yüzeyler arasında 10 tekrar sonrası 70 fibroblast, 10 kondroblast, 10 osteoblast ve 10 makrofajdan oluşan bir fibroz köprü gelişecektir.

Hematomun fibrinden oluşmuş ilk çatısı üzerine fibroblast ağırlıklı nadir kondroblast ve osteoblasttan oluşan bir bağ ve destek doku kompleksi gelişir. MKH'lerden yukarıdaki örnekte verilen şekilde sadece kondroblast ve osteoblastlar gelişmeyecektir. Hasar içinde kalan epitel doku, damar doku, kas doku, kemik iliği, sinir onarımı için gerekli başka doku öncül hücreleri (prekürsör=nöroblast, myoblast vb.) de gelişir.

\section{Çoğalan Kök Hücreler Hangi Dokuya Farklılaşacağına Nasıl Karar Verirler?}

a) Kırık bölgesine yakın hangi doku hasarlanmış ise hasarlı dokudan salınan sitokinler (büyüme faktörleri) bu farklılaşmayı belirlerler. illk dönemlerde fibroblastlardan salınan büyüme (growth) faktörlerin (FGF) ve plateletlerden salgılanan=derived büyüme faktörlerin (PDGF) etkisi lökositlerden salınan interlökinlerin etkilerinden daha fazla olacağından; matriksin kollajen tip II ve fibrinden zengin olmasını sağlarlar (kimyasal etki). b) Bu dönemde kırık uçlarını sabitlemek için kullandığımız tespit sistemlerinin stabilitesi hücre yüzeylerindeki siklinler ve integrinler gibi yüzey proteinleri üzerinden hücre çekirdeğine direkt mekanik etki yaparlar ve hücrenin hangi proteinleri sentezleyeceği belirlenir (mekanik etki).

Yüzey proteinlerinin mekanik uyaranlardan aldığı değişimlerin hücre çekirdeğine iletilmesiyle de hücrenin kaderi: proliferasyon, göç etme, yapışma, farklılaşma şekli belirlenir.

Eğer kırık uçları stabile yakın ise bu mekanik etkiler ile kollajen tip 1 sentezini arttırır. Eğer kırık uçları hareketli ise elastin ve fibronektin sentezini arttırır. Kırık uçlarında hareket olması ayrıca kollajen tip II ve hyalen sentezini de arttırır.

İlk günlerde iyileşme bitene kadar izlenen kırık yüzeyleri arasındaki köprü yapıda yapım ve yıkım işleri birlikte olur. İskemi nedeniyle; (a) hasarlı kemik dokuya komşu sağlam kemik kısmından Havers ve Volkman sistemindeki damar uçlarındaki (b) hasarlı yumuşak doku bölgesine en yakın sağlam kalmış yumuşak dokudaki damar uçlarındaki perisit adı verilen $\mathrm{KH}$ 'lerin çoğalması ve farklılaşması ile damar tomurcuklanmaları (anjiogenezis) başlar.

Travmanın direkt etkisi ya da iskemi sonucu gelişen nekroze kemik doku da istenmeyen bir dokudur ve inflamasyon ile önce yok edilmeli, sonrasında tamir edilmelidir

Sağlam komşu kemikte oluşan damar tomurcuklarının iskemik bölgenin içindeki kemik parçalarının içlerine ilerleyebilmesi için osteoklast ve makrofajlarca 


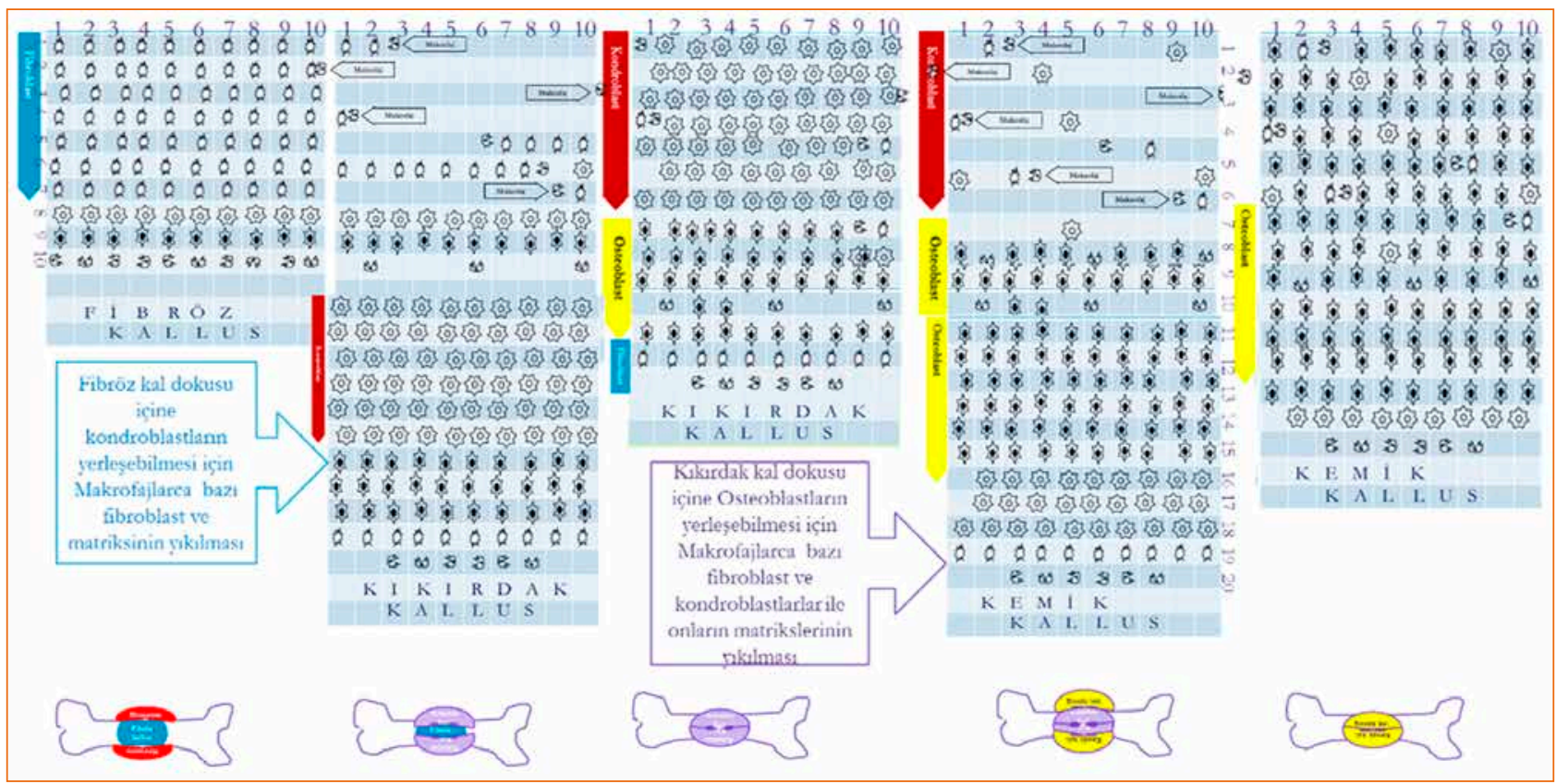

Şekil 4. Kırık hattında çoğalan kök hücrelerin fibro-kondro-osteoblast ya da makrofajlara farklılaşıp kaynamayı sağlamaları (şematik).

açılmış tünelleri kullanması gerekir. Tünellerin açılması işlemi sayesinde hasarlı kemik dokunun fragmante olması sağlanır. Bazen de bu parça kemikler fibröz ya da osteoid matriks ile kaplanıp tecrit edilirler.

Kırık hematomu üzerinden gelişmiş olan fibröz köprü matriksi çok sert ve katı olmadığından içerdiği hücrelerin ozmoz ve diffüzyon ile beslenmesine firsat tanır. Buna rağmen buraya en yakın sağlam doku içindeki damar perisitlerinin çoğalması ve farklılaşması ile gelişen yeni damar endoteli ile anjiogenezis başlar.

Yumuşak dokudan gelişen bu damar tomurcukları fibröz kallusun içine doğru büyür. Fibröz kallus gelişimi için tek kök hücre kaynağı damarlanmadaki perisitler değildir.

Bu dönemde köprü içine $\mathrm{MKH}$ başka nereden gelir diye düşünürsek; a) Dolaşan kandaki MKH'den hematom içinde kalanları vb.) kırık hattına en yakın bölgedeki nişlerdeki (kemik iliği ve kaslardaki satellite MKH'leri) hücreleri unutmamalıyız.

\section{KIKIRDAK KÖPRÜ (KALLUS) DÖNEMi}

İlk 10 günden sonra MKH'lerden çoğalma ve farklılaşması yukarıdaki örnekle devam edecek olursa bu sefer 10 kök hücreden: altı tanesi kondroblasta, üç tanesi osteoblasta, bir tanesi fibroblasta dönüşüm gösterecektir. Gene bazı kök hücreler damar endoteli, makrofaj, miyoblast, adipoz hücre vb. farklılaşacaktır.
Fakat 10 döngü sonucu ortamda 60 kondroblast, 30 osteoblast, 10 fibroblast, 3-5 makrofaj oluşacaktır.

Fakat bu yeni 100+(3-5) hücre için daha önce mevcut olan fibröz kallus içinde yer açılması gerekecektir. Bunun için bir önceki dönemde fibröz kallusu oluşturan 60 fibroblastın apopitoz veya başka yöntemler ile yıkılması bunların oluşturdukları matriksin makrofajlar ve enzimler ile parçalanması gerekir. Sonuçta yeni köprü (kallus): $60+10=70$ kondroblast, $30+10=40$ osteoblast, 10 fibroblast ve 10 makrofajdan olusan 130 hücrelik, matriksi de kollajen tip 2'den zengin kıkırdak kallustur.

Illk fibröz kallustaki gibi ve kıkırdak kallus dönemine ait matriks de çok yoğun olmadığı için moleküler difüzyon ve ozmoza izin verir. Bu nedenle bu dönemlerde köprüyü (kallusu) oluşturan dokular metabolik açıdan çok gelişmiş bir damar ağı olmaksızın da yaşamını sürdürebilirler.

Fibroz matriks, elastin ve fibrini bol içermesi nedeni ile kırık uçlarına etkiyen mekanik etkileri integrinler gibi yüzey proteinleri üzerinden hücre çekirdeklerine daha kolay iletir. Oysa kıkırdak kallus matriksi içindeki kollajen tip 2 ve hyalen molekülleri yüzünden fizyolojik güçlerin integrinler üzerinden kondroblast hücre çekirdeğine etkimesi fibroblastlardaki kadar kolay olmaz.

Kıkırdak kallus, fibröz kallusa göre daha rijit bir yapıdır. Bu rijidite matriks moleküllerinin yapısından kaynaklanır (Şekil 4). 
Sert kıkırdak kallus etrafındaki sağlam kemik ve yumuşak dokudan gelen damar tomurcuklarına ait endotelin kendi içine girmesine de kolay müsaade etmez, zaten doğası da bunu gerektirir. Kıkırdak kallus bu nedenle avaskülerdir.

\section{KEMIK KÖPRÜ (KALLUS) DÖNEMI}

21. günden sonra MKH'lerden çoğalma ve farklılaşmayı yukarıdaki örnekle tamamlarsak her 10 kök hücreden; altı tanesi osteoblasta,üç tanesi kondroblasta, bir tanesi fibroblasta dönüşecektir. Gene bazı kök hücreler damar endoteli, makrofaj, miyoblast, adipoz hücre vs farklılaşacaktır. Fakat 10 döngü sonucu ortamda 60 osteoblast, 30 kondroblast, 10 fibroblast, 3-5 makrofajdan oluşacak yeni bir doku ile karşılaşırız.

Bu sefer de yeni oluşmuş bu 100+ (3-5) hücre için daha önce mevcut olan kıkırdak kallus içinde yer açılması gerekir. Bunun için kıkırdak kallusu oluşturan 60 kondroblastın ve 10 fibroblastın apopitoz veya başka yöntemler ile yıkılması bunların oluşturdukları matriksin makrofajlar ve enzimler ile parçalanması gerekir. Sonuçta yeni köprü: $60+40=100$ osteoblast, $30+10=40$ kondroblast ve 10 fibroblast, beş makrofajdan oluşan 165 hücrelik matriksi de kollajen tip 1'den zengin bir kallustur.

Kırık sonrası 21. günden itibaren kırık uçları arasındaki köprü osteoblast hücrelerinin hakimiyeti altında ve kollajen tip 1'den zengin matriks ile doldurulur. Fibröz kallus ve kıkırdak kallus döneminde matriks çok yoğun olmadığı için moleküler difüzyon ve ozmoz daha kolay olmasına karşın kemik kallusta; kemik matriks hem diffüzyona ve ozmoza kolay firsat tanımaz hem de bazı osteoblastlar kendi oluşturdukları osteoid adı verilen matriks içinde sıkışıp kalmaya başlarlar. Metabolizmaları yavaşlar ve şekilleri değişmeye başlar, bu hücrelere osteosit adı verilir. Kırık sonrası birinci ay civarında kemik köprüyü oluşturan hücreler kısmen koloniler halinde dizilmeye başlasalar bile matrikslerindeki kollajen tip 1 lifleri belli bir düzen içermezler ve rastgele dizilirler. Rastgele dizilmiş kollajen tip 1 lifleri arasında yer yer kalsiyum minerali çöker. Düzensiz dizilmiş kollajen tip 1 lifleri arasındaki mineralize matriks histolojik ve radyolojik görüntülerde "Atılmış Pamuğa" benzediği için bu tür kemik dokuya "Woven kemik" de denir.

Kemik köprüyü oluşturan hücrelerin metabolik aktiviteleri bu matriks yüzünden çok yavaşlamıştır. Bu sırada gerek sağlam kemik gerek sağlam yumuşak dokudan gelen damar endotelleri bu bölgeye ulaşmıştır. Düzensiz kemik doku ve düzensiz damarlanma mevcuttur.

Yine de kaynama dokusu içinde çok sık olmasa da düzen oluşturmuş kollajen tip 1 lifleri arasındaki düzenli boşluklara kalsiyum mineralleri çöker. Kısıtlı da olsa mineralizasyonunu tamamlamış osteid matriksi saptanabilir.

\section{REMODELIZASYON DÖNEMi}

Kırık sonrası 45. günden sonra başlayıp 10-15 yıl kadar süren kırık dokusunun orijinal dokusu haline kadar geçen dönemdir. Özetlemek gerekirse düzensiz olan kemik doku matriksinin;

1 - Kollajen tip 1 liflerinin bu bölgelere gelen fizyolojik güçlere göre dizilip katmanlar (lameller) oluşturması,

2- Lameller yapının merkezinde damar endotelinin yerleşmesi,

3- 7-8 kattan oluşan katmanlar arasına osteositlerin dairesel olarak dizilmesi ve "Osteon"ların oluşmasidır.

Bu dönemi hematom, fibroz, kıkırdak ve kemik köprü dönemlerinden ayıran en önemli fark granülasyon dokusundaki damar tomurcuklanmalarının orijinal kemik dokuya ait bir düzene dönüşmesidir.

Çünkü kırık uçları arasındaki kemik kallus dokusundaki damarlanma embriyodaki primer ve sekonder kemikleşme merkezlerinin vaskülarizasyonuna benzer. Kemik köprü oluştuktan sonra yapım ve yıkım işlemlerini ayrı ayrı izlemek mümkün olmaz. Kök hücreler aynı anda hem osteoblatlara hemde osteoklastlara farklılaşmaktadır. Zaten kırık uçlarına en yakın sağlam kemik dokuda yapım ve yıkım işlemleri (remodalizasyon) doğal olarak devam etmektedir.

Kırık uçları arasındaki mesafe ne kadar az ise ya da torus kırığı gibi kemik dokunun kaybolmadığı durumlarda bu dönemleri ayrıntılı olarak gözlemek mümkün olmaz. Çok parçalı ya da kırık uçları arası mesafenin büyük olduğu kırıklarda kırık uçları arasındaki bölgede her dönem ayrıntılı izlenirken kemiğin ucundaki hasarlı bölgelerde ise bu dönemleri ayrıntılı olarak gözleyemeyebiliriz.

\section{PRIMER ve SEKONDER KIRIK IYILEŞMESi}

Erişkinde hasarlanan dokular kendilerini yenilemek için embriyodaki gelişimlerini taklit etmeye çalışırlar. Fakat erişkinde embriyonel kök hücreler (EKH) yerine hasarlı bölgeye en yakın nişlerdeki yetişkin tip MKH'ler veya dolaşan kandaki MKH'ler kullanılır. Embriyonel gelişim taklit edilmeye çalışııı iken aynı anda hasarlı dokunun da ortadan kaldırılmaya çalışılması fizyopatolojiyi tarif etmekteki diğer zorluktur.

Tıpkı embriyoda intramembranoz ossifikasyondaki olduğu gibi mezenkimal dokudan kemik dokuya geçiş arasında damarsız kıkırdak doku dönemi gözlenmez 
veya izlenemeyecek kadar kısa gözlenir ise buna primer kırık iyileşmesi adı verilir.

Fakat embriyodaki endokondral ossifikasyondaki gibi mezenkimal dokudan sonra, damarsız fibroz ve kondrablastik doku, bunu takiben düzensiz damarlanmalı bir kemik dokuya geçiş izlenir ise sekonder kırık iyileşmesi denir.

Primer kırık iyileşmesinde kırık uçları arası mesafe yoktur ya da çok azdır. Bu nedenle orijinal kemiğe ait matriks doku ve kemik damar sistemi bozulmamış kabul edilir. Hasarlı dokunun ortadan kaldırılması işlemi yoktur ya da gözlenemeyecek kadar azdır. Dolayısı ile iyileşme, tamir dokusu (reperation) granülasyon ile değil ilk hali gibi kemik dokusu (rejenerasyon) ile olur.

Kafa ve vücut yassı kemiklerinin embriyodaki oluşumu gibi erişkinde MKH'lerden osteoblastların gelişimi sırasında fibröz ve kıkırdak hücrelere ait dönemleri gözleyemeyiz. Embriyonal mezenkimal kök hücreler de yoğunlaşıp lamellar (kağıt para gibi) tarzda kemiklerin ilkel mezenkimal taslaklarını oluştururlar. Mezenkimal ilkel bu kemik taslaklara ektodermal veya endodermal germ yapraklarından gelişen damar yapılar gelir ve beslenmelerini sağlar. Bu taslakların içlerine ilerleyebilmesi için; kök hücrelerden gelişen fagositik hücreler tüneller açar. Her olay birlikte ve senkronize gelişir. Bir lamel geliştikten sonra ikinci lamel bunun üzerine gelişir, dokuya geçiş için önceki dokunun yıkılmasına ya da yok oluşuna gerek yoktur.

Sekonder kırık iyileşmesinde ise kırık uçları arası mesafe büyüktür ve bu boşluk derhal doldurulmalıdır. Orijinal dokuya dönmek için kök hücrelerden yeni dokunun oluşturulmasına kadarki sürede boşluğu dolduran geçici tamir dokusunun kaldırılması gerekir. Boşluk ilk olarak açık olan damar uçlarında bulunan bir bağ doku varyantı olan kan ve onun matriksi ile doldurulur. Kan doku içindeki fibrinojen fibrine dönerek matriksi yarı katı hale getirir. Fibrin matriks kırık uçları arası tamir dokusunun ilk çatısını (scaffold) oluşturur. Bu ilk yapı avaskülerdir, fakat kanama ile dolaşan kandaki MKH'leri ve fagositoz yapacak makrofajları çok az sayıda olsa da içerir. Tamir ve iyileşme için bu hücreler yetmeyecektir. İlave kök hücre kaynakları kırık bölgeye komşu kemik iliği (Ki) ve damar perisitlerindeki MKH'dir.

Erişkin kemik dokusu damar yapısı; a) organize kortikal kemik (Haversian ve Volkman kanalları) b) organize spongioz (medüller sinusoider ağı) ve c) periosteal damar ağı olarak üç yapıdan oluşmaktadır. Kırık oluşması anında hasarlı bölgedeki damar yapı bütünlüğü ve organizasyonu da bozulur. Kırığın tamiri ve iyileşmesi ancak bu damar ağlarının ve bu ağlara göre organize olmuş kemik hücreleri ile matriks lifsel yapılarının dizilimlerinin sağlanması ile olur.

\section{KIRIK IYYLEŞMESININ KONTROL EDILMESI}

Eğer tamir dokusu içinde fibroblast ağırlıklı ve düzensiz damar tomurcukları var ise patologlar iyileşme dokusunu 'Granülasyon Dokusu' olarak tarif ederler. Hasarlı doku içindeki damarların iyileşmesi ve dizilimine göre patologlar tanı koyarlar. Aşağıdaki iki neden kırık iyileşmesindeki granülasyon dokusunun oluşumunu açıklamaktadır;

1- Kırık oluşumunda damar bütünlüğü bozulmuş ve kırık hattında hematom oluşmuş ise hematom sonrası bölgede MKH çoğalıp ilk etapta daha çok fibroblastlara farklılaşacağı için,

2- İyi bir tespit yok ve kopan damar uçları arası mesafe uzun ise hasarlı dokudaki perisitlerden yeni damar oluşumu tomurcuklar halinde olacak karşı taraf damar ucuna ulaşamayıp anastomoz geliştiremeyecekleri için.

Kırık iyileşmesi bu granülasyon dokusunun gelişimini gözlemleyip çeşitli pozitif ya da negatif müdahaleler ile kontrol edilebilir. Bu özellikten yararlanarak ortopedi ve travmatoloji uzmanları kontrollü bir kırık oluşturup bu kırı̆ıın iyileşmesi esnasında granülasyon dokusunu istedikleri yöne yönlendirerek ekstremitelerdeki deformiteleri, eşitsizlikleri ve kemik eksikliklerini tedavi edebilirler. Primer kırık tedavilerinde de kullanılan tespit materyaline (dinamik çiviler, eksternal fiksatörler) göre kaynama gecikmesi ve yokluğunu ya da kötü kaynamalarını tedavi edebilirler.

\section{Granülasyon Dokusunun Hematom Döneminde Kontrolü}

Hasarlı yumuşak doku iyi tespit edilmiş ise damar uçları, sağlam kalmış son endotel bazal laminasını takip ederek damar lümenine göre doğrusal uzayarak iyileşir. Damar anastomozlarında tespit bu yüzden önemlidir.

Damar lümeni bozulması sonucu hematom kırık hattında kalır ve dış ortam ile temas etmez ise sorun olmaz, ama hematom dış ortam ile temas eder ise (açık kırık, kontaminasyon), bu şartlar granülasyon dokusu gelişimini negatif etkiler. MKH ortamdaki mikroorganizmaları veya bunlara ait antijenik yapıları (PAMP) yok etmek için çoğaldıktan sonra farklılaşmalarını makrofaj yönüne yapar. Kaynama gecikmesi ve infekte pseudoartrozlar oluşabilir.

MKH'lerin bağ ve destek dokuya dönüşmeyip makrofaj yönüne farklılaşmasının diğer sebepleri ise hasarIı dokudaki mikrorganizma dışı yabancı cisimler (taş, mermi, ortopedik implantlar) ve hasar sonucu hastanın parçalanmış kendi doku molekülleridir (DAMP). Kırık hattına konacak plak-vida, intrameduller çivi (iMÇ) kırık hattından uzaktan geçen eksternal fiksatör 
pininden daha fazla miktarda yabancı cisim reaksiyonuna (PAMP) dolayasıyla makrofaj üretimine sebep olacaktır. Kırık hattından uzaktan konacak pin kırık hattına plak-vida ve iMÇ'den daha az enerji ile uygulanacağından hastanın kendi doku moleküllerini daha az parçalayacak daha az DAMP ile buna bağlı daha az makrofaj üretimine neden olacaktır.

Hematom döneminde eksternal fiksatör uygulamak kırık hattından geçmeyeceğinden primer hematomu ve onun içindeki kök hücre ve primer iskeleyi de bozmayacaktır

\section{Granülasyon Dokusunun Inflamasyon Döneminde Kontrolü}

Damar lümenini oluşturan epitelin devamlılığı için perisitlerden oluşan yeni epitel boyu günde yaklaşık 1 mm'dir. Her iki uçta olduğu için iki uç arası günlük toplam $2 \mathrm{~mm}$ yeni damar epiteli oluşabilir.

illizarov tekniği ile osteotomi yaptıktan sonra ilk 5-7 gün beklemenin (latency period) amacı inflamasyonun azalması, damar lümenine uygun yeni damarlanmayı sağlamak ve tomurcuklanmayı önlemektir. Bekleme süresi içinde osteotomi hattında lümen hattını bozacak hareketi de önlemek gerekir. Amaç kırık hattında mümkün olan stabiliteyi elde etmek bu sayede anastomozun gerçekleşmesini sağlamaktır. Hareket olması damar tomurcuklanmaları ve buna bağlı kaynama gecikmelerine ve kaynama yokluğuna neden olur.

Sirküler eksternal fiksatör üç planda da tespit sağladığından kırık hattında en fazla hareketsizliği=stabiliteyi sağlar. Buna karşılık plak-vida ve iMÇ tespitleri iki planda kırık hattında stabilite sağlayabilirler.

Perisitlerden yeni damar oluşumu çocuklarda hızlı olduğundan bu süre çocuklarda beş güne kadar kısalabilir. Günlük uzatma (distraksiyon) mesafesinin 1 $\mathrm{mm}$ olması ise endotelin ve daha sonra osteoblastları oluşturacak kök hücrelerin çoğalma süresi ile ilişkilidir. Kemoterapi görmüş ve yaşlı hastalarda kök hücre çoğalma süresi uzadığından bu hızı yavaşlatarak (günde dört kerede) yapmak başarıyı yükseltir.

Travmanın kendi verdiği hasara ilave yeni damar hasarı oluşturmamak gerekir. Plak-vida uygulamak için periostun kemik etrafindan tamamen sıyrılmasına dolayısıyla periosteal kan akımının bozulmasına ve iMÇ uygularken endosteal kan akımının bozulmasına sebep olunur. Kan akımının minimal bozulması için oymasız çivi kullanmak ya da periosteal kan akımını daha az verecek, daha az invaziv yumuşak doku kesileri ve yaklaşımları (LISS=Less Invasive Stabilization Systems, MIPO=Minimally Invasive Plate Osteosynthesis, MIPPO=Minimally Invasive Percutaneous Plate Osteosynthesis vb.) ile plak yerleştirme teknikleri uygulanır. Oymalı çivi kullanmak Ki'deki nişlerdeki MKH kaybına neden olacaktır. Oysa eksternal fiksatör pinlerini uygularken, kemiğin sağlam kalmış periosteal ve endoestal kan akımı bozulmaz.

illizarov tekniği ile kortikomi yaparken teknik önemlidir. Yarım kortikotomi sonrası oluşturduğumuz oblik kırıkları takiben sağlam kalan medüller ve periosteal damar yapılarının yeni kemik dokuyu (regenerat) daha çabuk geliştirdiğini gözleriz. Hasarlı dokunun iyileşmesinde kan damarları ait olduğu dokunun (kemik, kas, tendon) metabolizmasına yardımcı olur. Bu doku içindeki nişlerde bulunan MKH'lerin çoğalmasına, farkıılaşmasına yardımcı olduğu gibi dolaşan kan ile yeni kök hücre ve birçok sitokinlerin de bölgeye gelmesine ve hasarlı dokunun parçalanması ile oluşan artıkların uzaklaşmasına da yardımcı olur.

İnflamasyon dönemi sonunda (1. hafta) osteotomi uçları arasında anastomoz gerçekleştiği kabul edilir. Distraksiyona başlanması istenir. Bu süre sonunda distraksiyona başlanmaz ise granülasyon dokusu sertleşir=konsolide olur. Uzatma gerçekleştirilemez.

Kontaminasyon ya da enfeksiyonlarda kök hücreler kaynama dokusunu sağlayacak mezenkimal dokulara dönüşmek yerine daha çok mezenkim kökenli fagositik ve immün cevabı arttıracak hücrelere dönüşmektedir. Hasarı tamir etmek yerine hasarı oluşturan etmeni ortadan kaldırmaya yönelik süreçler devam edecektir. Bu yüzden inflamasyon kırık iyileşmesi yönüne değil, infeksiyonu önlemeye yönelir (infekte pseudoartroz).

\section{Granülasyon Dokusunun Kıkırdak Kallus Döneminde Kontrolü}

Kırık hattında granülasyon dokusunda kıkırdak matriks ve kondroblastları gözler hale gelmek demek kırık boşluğunun büyük olması yani kırık uçları arası temasın az olması anlamına gelir. Kırık oluştuğu zaman kırık uçları iyi redükte ve tespit edilir ise Haversien sistem anastomozu çabuk gerçekleşir. Kırık hattında ölü osteositler ve mineralize kemik matriks osteoklastlarca temizlenir. MKH osteoblastlara farklılaşıp yeni kemik dokuyu (rejenerasyon) oluşturur. Kırık doku tamiri esnasında granülasyon dokusuna ait fibröz ve kıkırdak kallus görülmediği için primer kallus olarak tarif edilmiştir.

Kırık uçları arası mesafe çok ise veya iyi bir tespit yok ise Haversien damar uçları anastomoz yapamaz. Damar uçları karşı tarafı yakalamadığı zaman damar tomurcukları oluşur, fibröz ve kıkırdak kallus dokusu gözlenir. Kırık hattında hareket yok ise, periosteal damar ve yumuşak doku damar hattı anastomozları gerçekleştirir. Yumuşak doku içi MKH osteoblastik aktivite kazanarak heterotopik ossifikasyon ile yeni kemik doku oluşturur. Kırık tamiri esnasında her üç kallus 
(fibröz, kıkırdak, kemik) dokusu gözlendiği için sekonder kallus diye tarif edilir.

Kıkırdak doku matriksi kırık uçlarındaki harekete bağlı olarak kollajen Tip II ve proteoglikanlardan zengin bir yapıdadır. Mineralize olmaz ve ozmoz ile de beslenebilir.

Deformite ve uzatma tedavilerinde osteotomi hattındaki kırık uçlarında yapılan distraksiyonlar ile her gün yeni bir kırık hattı oluşturulur. Ameliyat öncesi hesaplanan uzatma miktarı $\mathrm{mm}$ cinsinden ne kadar ise günde $1 \mathrm{~mm}$ uzatma yapılır. Uzatma yapıldığı süre içinde kırık hattında kıkırdak kallus oluşur. $10 \mathrm{~cm}$ kısalık için $10 \times 10=100$ mm'lik uzatma gerekir, bu da 100 gün uzatma yapmak demektir. Yüz gün kırık hattında kıkırdak kallus oluşur, kırık hattı Büyüme plağı (Growth Plate) gibi davranır. Büyüme plağının üstündeki sekonder kemikleşme merkezi ve altındaki primer kemikleşme merkezi sayesinde uzun kemiklerin büyümesine benzer kemikleşme olur. 100 gün sonunda uzatmaya son verilir. $\mathrm{Bu}$ büyüme plağının arrestine (kapanmasına) benzer. Osteotomi hattında uzatma nedeni ile oluşan yeni kemik dokunun osteoid matriks yeterince mineralize olmadığı için uzatma bittiğinde uzatma bölgesinde radyolojik olarak kemikleşme gözlenemez. Uzatma bittiğinde mineralizasyonun hızlanması için osteotomi ve uzatma bölgesine fizyolojik yük verilmesine firsat tanınmalıdır. Uzatma bölgesinde uzayan kemiğe ait en az 3 kortekste mineralizasyon=konsolidasyon gözlenmesi eksternal fiksatör çıkarılması için yeterli bulgudur. Fakat kemoterapi görmüş hastalarda bu bulgulara güvenilmemelidir. Bu neden ile fiksatör çıkarılmadan somunlar gevşetilip fiksatör üzerinde aksiyel yüklenmeye izin verilmeli ve hasta tolere edebildiğinde fiksatör çıkarılmalıdır.

Kırık uçlarında ve kırık hattında Kirschner tellerinin gerginliğ̈inin firsat tanıdığı oranda kompresif/distraktif yüklenmeye firsat tanınmalıdır.

\section{Granülasyon Dokusunun Kemik Kallus Döneminde Kontrolü}

Kırık uçlarında harekete engel olunup sadece kemik uzun aksına paralel yüklenmeye firsat tanınmalıdır. Bu sayede en son distraksiyon periyodunda oluşturulmuş fibröz ve kıkırdak kallus arasında damar anastomozu sağlanır. MKH'lerin osteoblastlara farklılaşması ve kollajen Tip I'den zengin matriks üretmesi sağlanır. Şayet uzatma esnasında damar tomurcuklanmaları oluşmuş ise, kırık hattında kompresyon yaparak kırık hattında istemediğimiz fibröz kıkırdak matriks ve damar tomurcuklarının zedelenmesini ve inflamatuvar işlevin yenilenmesini sağlayabiliriz.

Kalsifikasyonun gecikmesinin bir başka sebebi ise uzatma bittikten sonra kırık bölgesine fizyolojik yüklerin uygulanmamasıdır. Uzatma sırasında ve bitiminde osteotomi hattına fizyolojik yüklerin binmesi için alt ekstremite uzatmalarında fiksatör ile ekstremiteye yük veren hastaların hızlı konsolidasyonlarının sebebi fizyolojik yüklenmedir. Schanz çivileri kullanıldığında ya da çivi yardımlı uzatmalarda ve tel gerginliği iyi ayarlanmadığı vakalarda konsolidasyon; tespit cihazlarının kırık hattına fizyolojik yük verilmesine izin veremeyeceğinden daha uzun sürecektir. Çivi ile uzatmalarda kilit vidalarının kazara kırıldığı vakalarda konsolidasyon süresinin kısalmasının sebebi budur.

Kilit vidalarının kırıldığı, medullaya göre ince konmuş çivilerde ise kırık bölgede fizyolojik olmayan yükler etkir, bu nedenle bu tür vakalarda kaynama gecikmeleri görülür. Kırık bölgesinde anguler, translasyonel ve rotasyonel instabiliteye sebep olan tüm fiksasyon cihazlarında kaynama gecikmesi ve kaynama olmamasının sebebi angiogenezisin tamamlanamamasıdır.

Üst ekstremite uygulamalarında ise fizyolojik yükler kompresif yönde olmamalı tersine distraktif yönde olmalıdır. Üst ekstremitede fizyolojik yüklenmeyi sağlamak için kırık hattının distalindeki halkaların distal taraf somunları gevşetilmelidir.

\section{KAYNAKLAR}

1. Ilizarov GA. The tension-stress effect on the genesis and growth of tissues: Part I. The influence of stability of fixation and sort tissue preservation. Clin Orthop Relat Res 1989;238:249-81. Crossref

2. Spiegelberg B, Parratt T, Dheerendra SK, Khan WS, Jennings $\mathrm{R}$, Marsh DR. Ilizarov principles of deformity correction. Review. Ann R Coll Surg Engl 2010;92(2):101-5. Crossref

3. Kaljumae $U$, Martson A, Haviko $T$, Hanninen $O$. The effect of lengthening of the femur on the extensors of the knee. An electromyographic study. J Bone Joint Surg Am 1995;77(2):247-50. Crossref

4. Ilizarov GA, Lediaev VI, Shitin VP. The course of compact bone reparative regeneration in distraction osteosynthesis under different conditions of bone fragment fixation (experimental study). Eksp Khir Anesteziol 1969;14(6):3-12.

5. Appelbaum FR, Forman SJ, Negrin RS, Blume KG, editors. Thomas' Hematopoietic Cell Transplantation: Stem Cell Transplantation, 4th ed. US: Wiley, Blackwell Publishing Ltd.; 2004.

6. Nurse P. Cyclin dependent kinases and cell cycle control (nobel lecture). Chembiochem 2002;3(7):596-603. Crossref

7. Yamanaka S, Blau HM. Nuclear reprogramming to a pluripotent state by three approaches. Nature 2010;465(7299):704-12. Crossref

8. Chamberlain G, Fox J, Ashton B, Middleton J. Concise review: mesenchymal stem cells: their phenotype, differentiation capacity, immunological features, and potential for homing. Stem Cells 2007;25(11):2739-49. Crossref

9. Friedenstein AJ, Petrakova KV, Kurolesova AI, Frolova GP. Heterotopic transplants of bone marrow. Transplantation 1968;6(2):230-47. Crossref

10. Can A. Kök Hücre Biyolojisi, Türleri ve Tedavide Kullanımları, Bölüm 2-8. 1. Baskı. Ankara: Akademisyen Tıp Kitapevi; 2014. ss.50-288. 